\title{
LIDAR-DERIVED ELEVATION MODELS FOR HOMER, ALASKA
}

J. Barrett Salisbury, Ronald P. Daanen, and Andrew M. Herbst

Raw Data File 2021-2

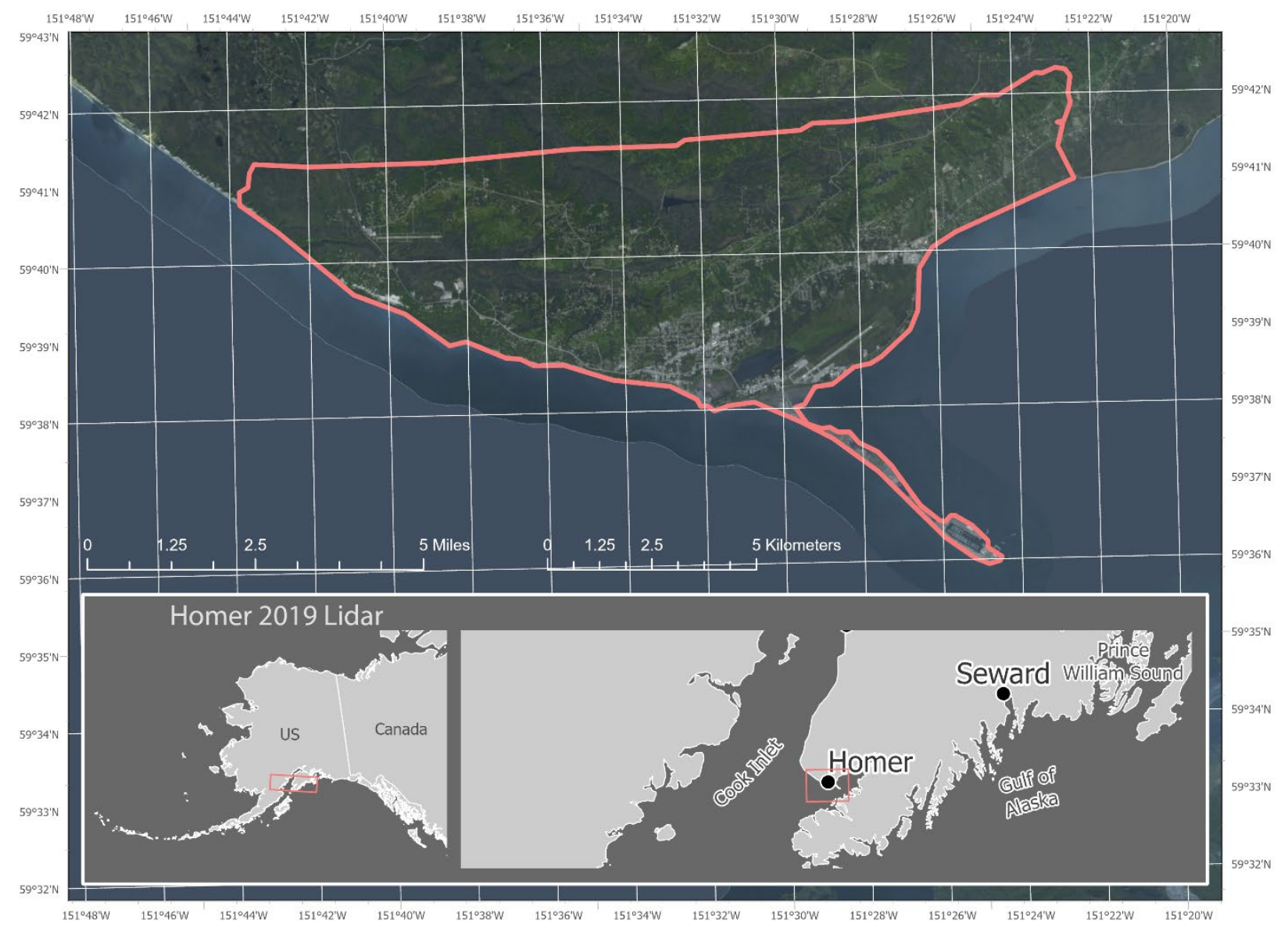

This report has not been reviewed for technical content or for conformity to the editorial standards of DGGS.

2021

STATE OF ALASKA

DEPARTMENT OF NATURAL RESOURCES

DIVISION OF GEOLOGICAL \& GEOPHYSICAL SURVEYS

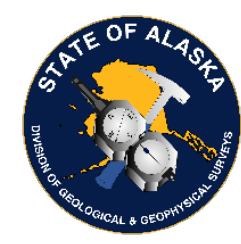


STATE OF ALASKA

Mike Dunleavy, Governor

DEPARTMENT OF NATURAL RESOURCES

Corri A. Feige, Commissioner

DIVISION OF GEOLOGICAL \& GEOPHYSICAL SURVEYS

Steve Masterman, State Geologist \& Director

Publications produced by the Division of Geological \& Geophysical Surveys are available to download from the DGGS website (dggs.alaska.gov). Publications on hard-copy or digital media can be examined or purchased in the Fairbanks office:

Alaska Division of Geological \& Geophysical Surveys (DGGS)

3354 College Road | Fairbanks, Alaska 99709-3707

Phone: 907.451 .5010 | Fax 907.451.5050

dggspubs@alaska.gov | dggs.alaska.gov

DGGS publications are also available at:

Alaska State Library, Historical

Collections \& Talking Book Center

395 Whittier Street

Juneau, Alaska 99801

Alaska Resource Library and

Information Services (ARLIS)

3150 C Street, Suite 100

Anchorage, Alaska 99503

\section{Suggested citation:}

Salisbury, J.B., Daanen, R.P., and Herbst, A.M., 2021, Lidar-derived elevation models for Homer, Alaska: Alaska Division of Geological \& Geophysical Surveys Raw Data File 2021-2, 6 p.

https://doi.org/10.14509/30591
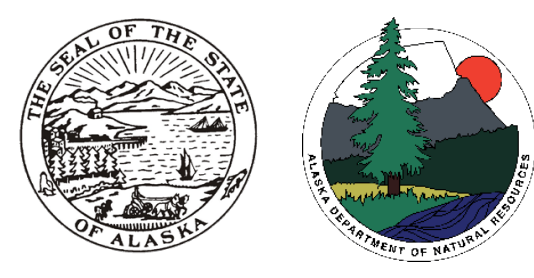


\title{
LIDAR-DERIVED ELEVATION MODELS FOR HOMER, ALASKA
}

\author{
J. Barrett Salisbury', Ronald Daanen ${ }^{1}$, and Andrew Herbst ${ }^{1}$
}

\section{INTRODUCTION}

The Alaska Division of Geological \& Geophysical Surveys (DGGS) used lidar to produce digital terrain models (DTM), a digital surface model (DSM), and an intensity model for Homer, Alaska. Detailed bare earth elevation data for Homer were collected and processed for use in a landslide hazard resiliency project for the City of Homer. Data coverage includes neighboring Kachemak City. Lidar and Global Navigation Satellite System (GNSS) data were collected on June 3, 2019, and subsequently processed using TerraSolid ${ }^{\mathrm{mw}}$ and ArcGIS ${ }^{\mathrm{m}}$. The Alaska Division of Mining, Land, \& Water (DMLW) Survey Section conducted a targeted Ground Control Survey for this project on June 19-20,2019. These data are being released as a Raw Data File with an open end-user license. All files can be downloaded for free from the DGGS publications website at https://doi.org/10.14509/30591.

\section{LIST OF DELIVERABLES}

Classified Points

Digital Surface Model (DSM)

Digital Terrain Model (DTM)

Hydro-Flattened DTM

Lidar Intensity Image

Metadata

\section{MISSION PLAN}

\section{Aircraft and Instrument}

DGGS operates a Riegl VUX1-LR laser scanner with a GNSS and Northrop Grumman Inertial Measurement Unit (IMU). The integration was designed by Phoenix LiDAR systems. The sensor can collect up to 820,000 points per second over a $150 \mathrm{~m}$ range. We flew the instrument with a repetition rate of 400,000 pulses per second, a scan speed of 200 revolutions per second, at approximately $200 \mathrm{~m}$ above ground level, and at a ground speed of approximately 40 meters per second with a fixed-wing Cessna 185. The scan look angle operated between 55 and 305 degrees. The total data coverage is approximately $98 \mathrm{~km}^{2}$.

\section{Weather Conditions and Flight Times}

DGGS collected lidar data on June 3, 2019, initiating the GNSS base station at $08 \mathrm{~h} 48$ and flying from $10 \mathrm{~h} 15$ to $15 \mathrm{~h} 35$ with a 15 -minute refuel at $14 \mathrm{~h} 15$. The sky was clear with light, easterly winds. Heavy air traffic precluded sufficient scanning of the southwestern portion of Beluga Lake

\footnotetext{
${ }^{1}$ Alaska Division of Geological \& Geophysical Surveys, 3354 College Road, Fairbanks, Alaska 99709
} 
and an area southeast of the Homer Airport runway (along Kachemak Drive). The low-quality data at the southwest end of Beluga Lake has been clipped and flattened to lake level.

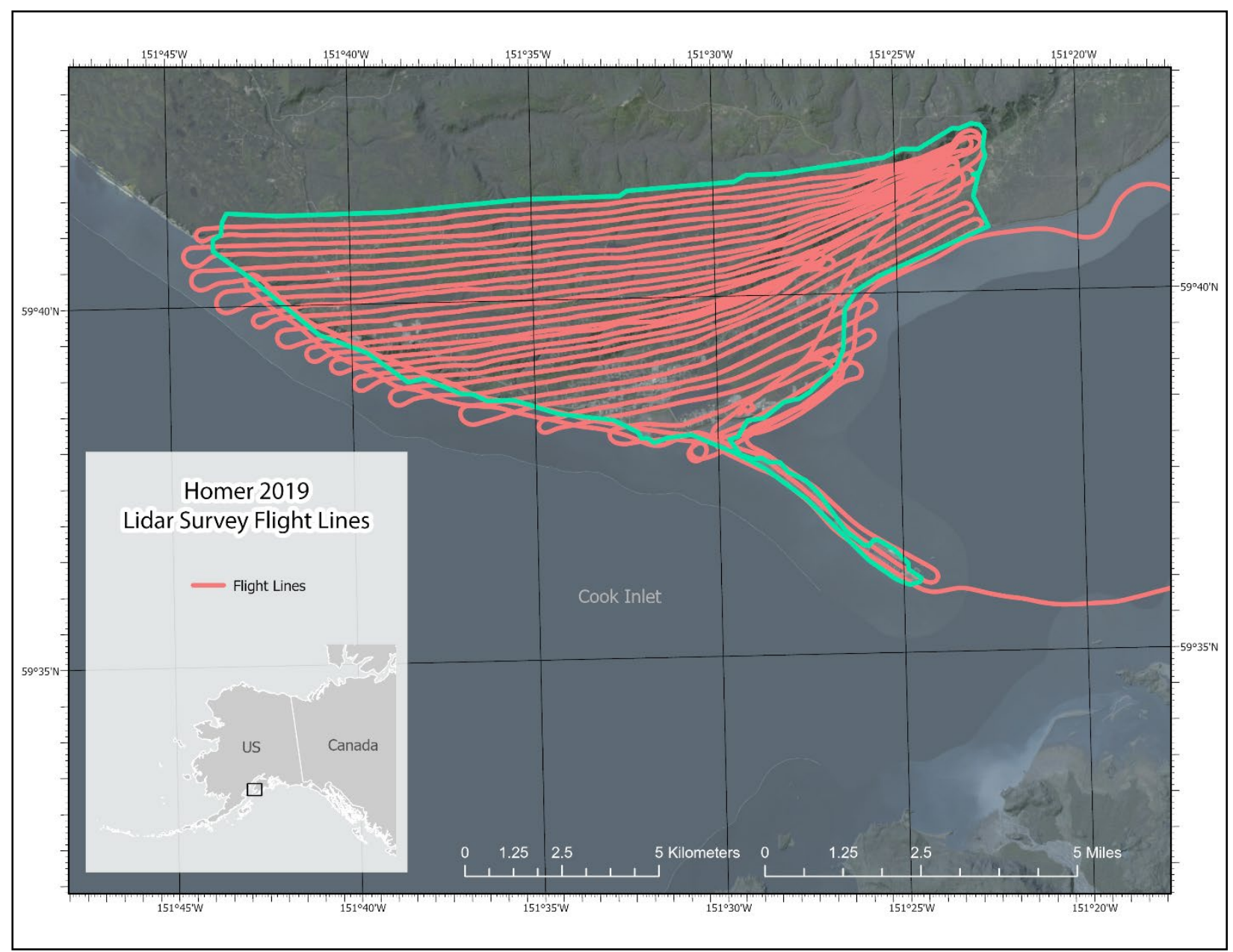

Figure 1. Project flight lines.

\section{PROCESSING REPORT}

\section{Lidar Dataset Processing}

DGGS processed raw data by first using SDCImport ${ }^{\mathrm{TM}}$ to apply range thresholding, reflectance thresholding, and missed-time-around (MTA) disambiguation for preliminary point cloud noise filtering. We coupled in-flight IMU and GNSS data in Inertial Explorer ${ }^{\mathrm{rm}}$ to produce flight trajectory data and coupled the trajectory data with the raw point cloud in Spatial Explorer ${ }^{\mathrm{Tm}}$.

We then used Terrasolid ${ }^{\mathrm{Tm}}$ to calibrate point cloud data using tielines for roll, pitch, and yaw of the aircraft during the survey. We completed this process first for all points, then on a perflight-line basis. For additional calibration, we identified interswath fluctuations in preliminarilyclassified ground points using overlapping tielines. We classified the point cloud in accordance with American Society for Photogrammetry and Remote Sensing (ASPRS) guidelines using 
project-tailored macros, resulting in a ground points class, as well as low, medium, and high vegetation (0.01-0.3 m, 0.3-5 m, and 5-60 m heights above the ground, respectively). Misclassified points were manually reclassified in post-processing QA/QC. We eliminated all low points and air points from the dataset and manually identified some buildings under dense vegetation, particularly in areas of complex terrain. We hydro-flattened the Bridge Creek Reservoir, Beluga Lake, and Lampert Lake to specified elevations. Lastly, we converted the point cloud from ellipsoidal to orthometric heights using GEOID 12B, then uniformly adjusted the dataset to maintain a mean offset of $0 \mathrm{~m}$ with collected ground control.

All derivative products were created in ArcMap. The DTM and DSM were produced using point triangulation with nearest-neighbor interpolation. The DTM was derived from all returns for ground classified points, while the DSM used first returns for all non-noise classes. A lidar intensity image was created from first returns of all classes using mean binning.

\section{Classified Point Cloud}

Classified point cloud data is provided in this collection in compressed ${ }^{\star}$. LAZ format. Data are classified in accordance with ASPRS 2014 guidelines and contain return and intensity information. Elevation surfaces interpolated from areas with a point density of fewer than $4 \mathrm{pts} / \mathrm{m}^{2}$ were classified as "no data."

\section{Digital Surface Model}

DSMs represent surface elevations as they appear to the naked eye. They include the heights of vegetation, buildings, bridges, etc. The DSM is a single band, 32-bit GeoTIFF file, with a ground sample distance of 0.5 meters. No Data value is set to $-3.40282306074 \mathrm{e}+038$.

\section{Digital Terrain Model}

DTMs represent surface elevations of ground surfaces, achieved by penetrating or flattening any vegetation, bridges, buildings, and other non-ground features. The DTM is a singleband, 32-bit float GeoTIFF file, with a ground sample distance of 0.5 meters. No Data value is set to $-3.40282306074 \mathrm{e}+038$.

\section{Hydro-Flattened DTM}

The hydro-flattened DTM represents bare earth surfaces which have undergone a selective "flattening" process, where elevation values for any hydrologic features are replaced with a consistent, appropriate pixel (elevation) value. The hydro-enforced DTM is a single-band, 32-bit float GeoTIFF file, with a ground sample distance of 0.5 meters. No Data value is set to $3.40282306074 \mathrm{e}+038$.

\section{Lidar Intensity Image}

The lidar intensity image describes the relative amplitude of reflected signals contributing to the point cloud. Lidar intensity is largely a function of scanned object reflectance in relation to the signal frequency, is dependent on ambient conditions, and is not necessarily consistent between separate scans. The intensity image is a single-band, 32-bit float GeoTIFF file with a 
ground sample distance of 0.5 meters. No Data value is set to $-3.40282306074 \mathrm{e}+038$ (32-bit, floating-point minimum).

\section{SURVEY REPORT}

\section{Ground Control and Accuracy}

The Alaska Division of Mining, Land, \& Water Survey Section collected 79 points in a targeted Ground Control Survey in Homer on June 19-20, 2019.

\section{Coordinate System and Datum}

All data are processed and delivered in UTM5 NAD83 (2011) and vertical datum NAVD88 with a GEOID correction following the latest GEOID12B for Alaska.

\section{Horizontal Accuracy}

Horizontal accuracy was not measured for this collection.

\section{Vertical Accuracy}

The relative accuracy for this dataset is $10.38 \mathrm{~cm}$ RMSE, calculated as the interswath consistency. The non-vegetated vertical accuracy for classified ground point data is a root mean square error of $3.1 \mathrm{~cm}$. The average pulse spacing is $18.56 \mathrm{~cm}$ and the average point density is 29 points per square meter.

\section{Data Consistency and Completeness}

This is a partial release dataset. After the refuel stop, the survey moved across Kachemak Bay to scan the north-facing flank of the Grewingk Glacier valley (the site of a 1967 landslide into the proglacial lake). Data covering the Grewingk Glacier landslide scar will be published separately. However, data quality portrayed here for Homer and Kachemak is consistent throughout the entire dataset.

\section{ACKNOWLEDGMENTS}

These data were collected and processed by the Alaska Division of Geological \& Geophysical Surveys staff with funding by the Federal Emergency Management Agency (FEMA) through Cooperating Technical Partnership (CTP) with the City of Homer and AK DGGS under federal grant number CTP EMS-2018-CA-00016-S01. 


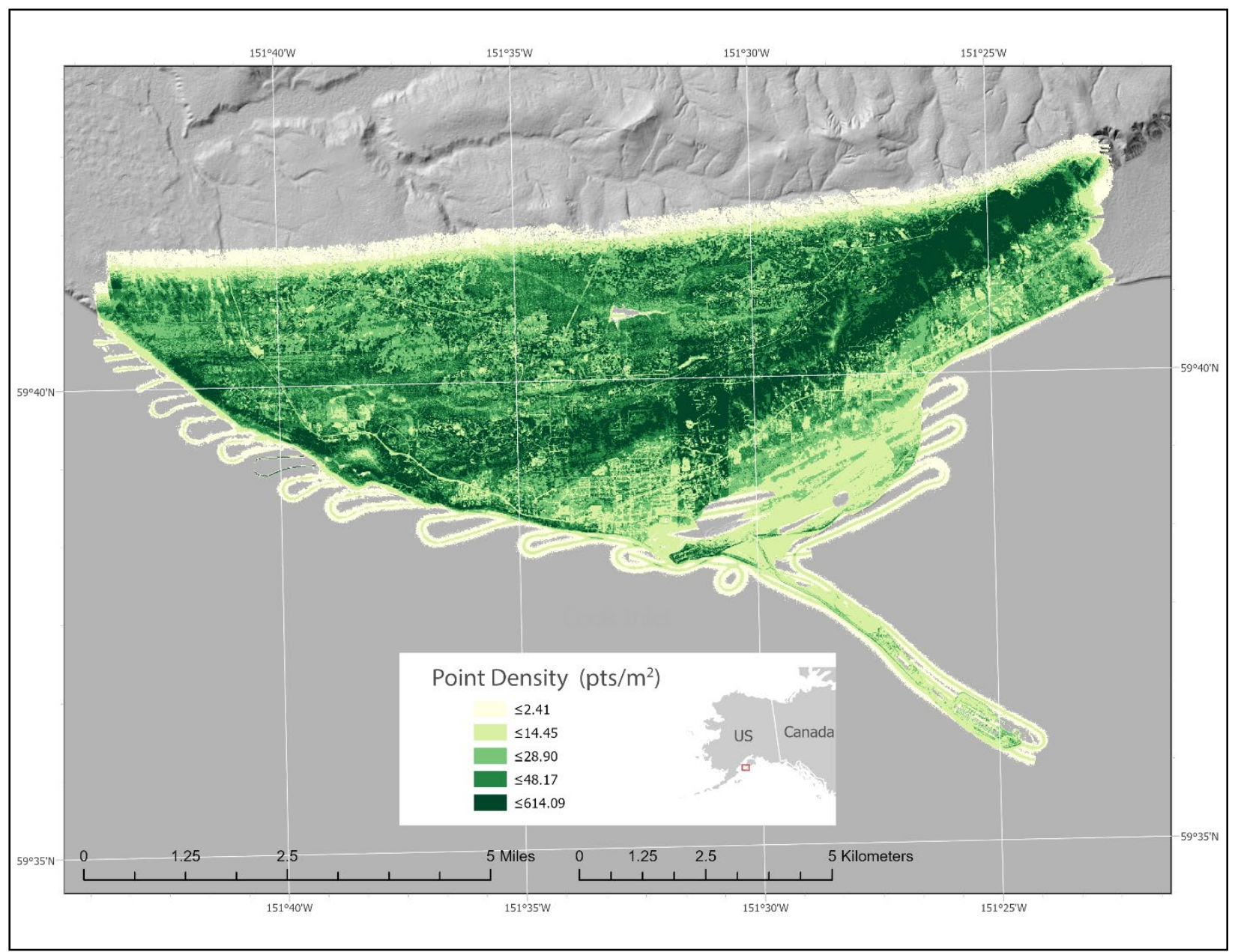

Figure 2. Point density displayed as 1-meter raster for the survey. 


\section{Appendix 1. Checkpoints}

\begin{tabular}{|l|r|r|r|r||r||}
\hline \multirow{2}{*}{ Number } & \multicolumn{1}{|c|}{} & & & \multicolumn{1}{|c|}{$\begin{array}{l}\text { Zz Elevation } \\
\text { Difference }(\mathrm{m})\end{array}$} \\
\hline \hline BE_5004 & 580635.927 & 6612533.982 & 53.735 & 53.75 & 0.015 \\
\hline BE_5011 & 577684.323 & 6613704.249 & 221.075 & 221.07 & -0.005 \\
\hline BE_5013 & 582089.658 & 6612343.381 & 22.083 & 22.08 & -0.003 \\
\hline BE_5058 & 581728.378 & 6616717.417 & 285.834 & 285.85 & 0.016 \\
\hline BE_5066 & 583843.713 & 6615651.758 & 357.632 & 357.67 & 0.038 \\
\hline BE_5073 & 586770.381 & 6617829.908 & 425.181 & 425.2 & 0.019 \\
\hline BENCHMARK_BM 4 & 589714.493 & 6608107.084 & 7.712 & 7.71 & -0.002 \\
\hline NAIL_NAIL3 & 588041.324 & 6615621.985 & 28.434 & 28.54 & 0.106 \\
\hline URBAN_5008 & 579796.212 & 6612613.893 & 67.457 & 67.41 & -0.047 \\
\hline URBAN_5010 & 577672.012 & 6613710.098 & 221.541 & 221.52 & -0.021 \\
\hline URBAN_5034 & 588021.495 & 6615616.825 & 28.081 & 28.09 & 0.009 \\
\hline URBAN_5051 & 580326.407 & 6614882.079 & 284.171 & 284.15 & -0.021 \\
\hline URBAN_5068 & 585452.944 & 6616387.049 & 344.232 & 344.22 & -0.012 \\
\hline URBAN_5072 & 586768.984 & 6617806.595 & 424.992 & 425.01 & 0.018 \\
\hline BE_5006 & 579733.917 & 6612602.377 & 64.482 & 64.47 & -0.012 \\
\hline BE_5037 & 589369.308 & 6616889.273 & 75.511 & 75.48 & -0.031 \\
\hline BE_5044 & 584781.612 & 6614377.014 & 56.403 & 56.39 & -0.013 \\
\hline BE_5052 & 580330.363 & 6614870.042 & 283.271 & 283.25 & -0.021 \\
\hline BE_5069 & 585443.523 & 6616397.515 & 343.668 & 343.7 & 0.032 \\
\hline PK_PK 1 & 583850.691 & 6615639.49 & 357.836 & 357.86 & 0.024 \\
\hline PK_PK 2 & 580636.745 & 6612538.878 & 53.408 & 53.42 & 0.012 \\
\hline URBAN_5023 & 587575.238 & 6609392.438 & 7.495 & 7.46 & -0.035 \\
\hline URBAN_5043 & 584801.463 & 6614351.444 & 54.461 & 54.46 & -0.001 \\
\hline URBAN_5061 & 581850.268 & 6615457.607 & 328.778 & 328.78 & 0.002 \\
\hline
\end{tabular}

\begin{tabular}{||l||r|}
\hline Average dz (m) & 0.003 \\
\hline \hline Minimum dz (m) & -0.047 \\
\hline \hline Maximum dz (m) & 0.106 \\
\hline $\begin{array}{l}\text { Average magnitude } \\
(\mathrm{m})\end{array}$ & 0.021 \\
\hline \hline $\begin{array}{l}\text { Root mean square } \\
\text { error (m) }\end{array}$ & 0.03 \\
\hline $\begin{array}{l}\text { Standard Deviation } \\
(\mathrm{m})\end{array}$ & 0.031 \\
\hline
\end{tabular}

